\title{
Clinacanthus Nutans Induces Antiproliferative and Apoptosis in Human Breast Cancer Cells Through Targeted Apoptosis Pathway
}

\author{
Hasni Arsad ( $\nabla$ hasniarsad@usm.my) \\ Universiti Sains Malaysia \\ Noor Zafirah Ismail \\ Universiti Sains Malaysia Institut Perubatan dan Pengigian Termaju \\ Salwani Md Saad \\ Universiti Sains Malaysia Institut Perubatan dan Pengigian Termaju \\ Ismail Abiola Adebayo \\ Kampala International University - Western Campus \\ Zaleha Md Toha \\ Universiti Sains Malaysia Institut Perubatan dan Pengigian Termaju \\ Rafedah Abas \\ Universiti Sains Malaysia Institut Perubatan dan Pengigian Termaju \\ Nur Nadhirah Mohamad Zain \\ Universiti Sains Malaysia Institut Perubatan dan Pengigian Termaju
}

\section{Research Article}

Keywords: Clinacanthus nutans, Apoptosis, Breast cancer, Antiproliferative activity, Gene expression, Western blot

Posted Date: January 12th, 2022

DOI: https://doi.org/10.21203/rs.3.rs-1150677/v1

License: (c) (i) This work is licensed under a Creative Commons Attribution 4.0 International License. Read Full License 


\section{Abstract}

Clinacanthus nutans dichloromethane fraction (CN-Dcm) extract has previously been proven to suppress breast cancer (MCF7) cell proliferation. Despite this, the molecular mechanisms involved in C. nutans extract-treated MCF7 cells are unknown. Hence, the molecular mechanism of apoptosis in treated MCF7 was investigated in this current study. This study was intended to subfractionate CN-Dcm extract using column chromatography and analysed the treated MCF7 cells using the CellTiter $96 \AA$ AQueous One Solution Cell Proliferation (MTS) assay, Annexin V/propidium iodide (PI) assay, western blot and reverse transcription-qualitative polymerase chain reaction (RT-qPCR). Out of nine subfraction extracts (SF1 to SF9), SF2 extract strongly inhibited MCF7 cells with the lowest $I_{50}$ value $(23.51 \pm 0.99 \mu \mathrm{g} / \mathrm{mL})$ and substantially induced apoptosis in the MCF7 cells. SF2 extract significantly downregulated BCL-2 expression and upregulated P53, BAX, BID, BCL-2, caspase-8, caspase-9 and caspase-3 expressions in treated MCF7 cells. Therefore, SF2 extract was analysed using liquid chromatography coupled to quadrupole time-of-flight mass spectrometry (LC-QTOF-MS), which confirmed the presence of bioactive chemical compounds. Thus, it can be concluded that the compounds found in SF2 extract may potentially cause apoptosis in MCF7 cells through intrinsic and extrinsic pathways.

\section{Introduction}

Despite various treatments and preventive approaches such as radiation therapy and surgery, breast cancer continues to be an important public health problem, as breast cancer has the second highest incidence of all types of cancers (Britt et al. 2020). Global Cancer Incidence, Mortality and Prevalence stated that women's breast cancer (11.7\%) exceeded lung cancer (11.4\%) as the most frequently diagnosed cancer (Sung et al. 2021). Krauss and Stickeler (2020) reported that $75 \%$ of breast cancer cases are reported to express the oestrogen receptor as this hormone promotes breast cells to grow in an uncontrolled way. Breast cancer (MCF7) is a favoured cell line, owing to its responsiveness to the hormonal oestrogen receptor (Levenson and Jordan 1997). Compared to other types of breast cancer cell lines, MCF7 is a suitable model to be used for in vitro and in vivo hormonal response analysis. MCF7 functions well when the cells are introduced into xenograft models compared to other breast cancer cell lines (e.g. SKBR3 cells and MDA-MB-453) (Welsh 2013; Ismail et al. 2020).

Cancer imposes a tremendous price on society as it affects both patients and their families with burdensome and debilitating effects due to long-term curative and palliative care regimens that are expensive and result in a consequential loss of morbidity and mortality (Yabroff et al. 2011). Chemotherapy drugs are one of the therapeutic strategies for cancer treatment. However, these drugs have strong side effects (Sak 2012) with inconsistent clinical responses and resistance development, which eventually leads to cancer progression and recurrence (Greenwell and Rahman 2015). Hence, it is important to discover a non-toxic, inexpensive, easily available and efficient drug candidate to treat cancer (Greenwell and Rahman 2015; Fu et al. 2018). Many herbal remedies and alternative treatments have been developed using medicinal plants for decades. Clinacanthus nutans is a member of the Acanthaceae family, often found in Thailand, Malaysia, China, Indonesia and Vietnam (Chelyn et al. 2014; Ismail et al. 2018). This plant has demonstrated many pharmacological benefits, including anticancer, antidiabetic, anti-inflammatory and able to treat insect bites, skin conditions and fever (Alam et al. 2016; Kamarudin et al. 2017). As demonstrated by Siew et al. (Siew et al. 2014), 17\% of the consumers used $C$. nutans as an ethnobotanical treatment, in which twelve consumers used $C$. nutans for cancer treatment and to prevent relapse.

Cancer research has shown a lack of validation in molecular mechanisms, making chemotherapeutic drugs less effective (Kaur et al. 2020). If the plant leaves contain phytochemicals that inhibit breast cancer cells, the mechanism of action must be investigated in order to identify molecular targets that can be used to develop a more effective, targeted and selective anti-breast cancer drug. Previously, we found that the dichloromethane (CN-Dcm) extract from C. nutans leaves had supressed the MCF7 cells growth, while also being less cytotoxicity towards normal breast (MCF 10A) cells (Ismail et al. 2020). However, the mechanisms by which treated MCF7 cells undergo apoptosis remain unknown. Hence, the goals of this study were to evaluate the effect of MCF7 and MCF 10A cells proliferation using the CellTiter 96® AQueous One Solution Cell Proliferation (MTS) assay and apoptosis effect using Annexin V/ propidium iodide (PI) assay. The quantitative reverse transcription-polymerase chain reaction (RT-PCR) and western blot were employed to validate the cellular process and cell death mode from the related molecular mechanism induced in MCF7 cell treatments. Liquid chromatography coupled to quadrupole time-of-flight mass spectrometry (LC-QTOF-MS) was used to determine the phytochemical compounds of the $C$. nutans extract.

\section{Materials And Methods}

\subsection{Plant source}

C. nutans obtained from HERBagus Sdn Bhd, Malaysia was recognised by the Herbarium Department of the School of Biological Sciences, Universiti Sains Malaysia with voucher number assigned was 11536 (Fig. S1). Additionally, C. nutans was authenticated using deoxyribonucleic acid (DNA) barcoding markers with accession numbers of KX014785.1 to KX014787.1 (matK) and KU985403.1 to KU985412.1 (rbcL and psbA-trnH) (Ismail et al. 2018).

\subsection{Subfractionation of CN-Dcm extract}

The CN-Dcm extract was prepared based on the method described by Ismail et al. (2020). In this study, CN-Dcm extract (10 g) was chromatograped using 0.040 to $0.063 \mathrm{~mm}$ silica gel (Merck, Darmstadt, Germany) packed into the column chromatography (40 mm) (Fig. 1). The slurry silica gel was prepared by dissolving the silica gel with $n$-hexane solvent. The $\mathrm{CN}$-Dcm extract was then added to the packed column at the top. The column was then subjected to solvent systems containing varying ratios of $n$-hexane to ethyl acetate $(\mathrm{H}: \mathrm{EA})$. Following that, a column was filled with another solvent mixture, chloroform to methanol (CHL:MEOH). Finally, 100\% methanol was flushed into the column. A small eluent from subfraction extracts was placed on a 
thin-layer chromatography (TLC) plate (Merck, Darmstadt, Germany) and those that had similar retention factor ( $\left.R_{f}\right)$ values were pooled together. Then, the TLC plate was sprayed with vanillin with sulphuric acid (Qrec (Asia), Malaysia). The vanillin (15 g) was dissolved in $250 \mathrm{~mL}$ of ethanol. The dissolved vanillin was diluted with $2.5 \mathrm{~mL}$ of sulphuric acid. The TLC plate was dried for 15 to 20 mins in a $100^{\circ} \mathrm{C}$ hot air oven. The subfraction extracts were lyophilised and stored at $-80^{\circ} \mathrm{C}$ until needed.

\subsection{Cell culture}

Both cells were acquired from the American Type Culture Collection (Manassas, Virginia, USA). The normal breast, MCF 10A cells were grown in Dulbecco's Modified Eagle Medium (DMEM) (Gibco, Paisley, UK) complemented with $0.5 \mathrm{mg} / \mathrm{mL}$ hydrocortisone (Gibco, Paisley, UK), $20 \mathrm{mg} / \mathrm{mL}$ epidermal growth factor (Gibco, Paisley, UK), 5\% horse serum (Gibco, Paisley, UK), 1\% PenStrep and $10 \mu \mathrm{g} / \mathrm{mL}$ insulin (Gibco, Paisley, UK). The MCF7 cancer cells were cultured in the Roswell Park Memorial Institute Medium 1640 (RPMI-1640) supplemented with 10\% (v/v) fetal bovine serum (FBS) (Nacalai Tesque, Kyoto, Japan) and $1 \%(\mathrm{v} / \mathrm{v})$ PenStrep (Gibco, Paisley, UK). Both cells were incubated with $5 \%$ carbon dioxide $\left(\mathrm{CO}_{2}\right)$ in a $37^{\circ} \mathrm{C}$ incubator. When the cells reached confluence, the old medium was decanted from the flask. An amount of $3 \mathrm{~mL}$ phosphate-buffered saline (PBS) (Nacalai Tesque, Kyoto, Japan) was transferred to the flask in order to remove the old media and dead cells. The flask was then filled with $200 \mu \mathrm{L}$ of $0.25 \%$ Trypsin-EDTA (Gibco, Paisley, UK) and incubated for 5 mins in the incubator to detach the cells. The trypsinization process was significantly enhanced by delicately tapping the flask. In order to inactivate the trypsin, $3 \mathrm{~mL}$ of medium was subsequently added to the flask and centrifuged for $5 \mathrm{mins}$ at $300 \mathrm{x}$. After removing the supernatant, the cell pellet was resuspended with a new medium.

\subsection{MTS assay}

Both cells with density of $1 \times 10^{4}$ cells/mL were added to a 96-well plate and incubated for $24 \mathrm{~h}$. The extracts were resuspended in $100 \%$ dimethyl sulfoxide (DMSO). The MCF7 cells were treated with serial diluted crude and fraction extracts $(0-300 \mu \mathrm{g} / \mathrm{mL})$ and subfraction extracts $(0-200 \mu \mathrm{g} / \mathrm{mL})$. In addition, $0.1 \%$ DMSO was used as a negative control while tamoxifen (Nacalai Tesque, Kyoto, Japan) was served a positive control. To ensure that the maximum concentration of DMSO in the treatment of cells was within the range of $0.1-0.5 \%$ (Scambia et al. 1994), the $0.1 \%$ of DMSO working solution was used. Additionally, MCF 10A cells have been treated to measure the selectivity index (SI) values. The MCF 10A cells were treated with serial dilution ranging from 0 to $1200 \mu \mathrm{g} / \mathrm{mL}$ for crude and fraction extracts and 0 to $1000 \mu \mathrm{g} / \mathrm{mL}$ for subfraction extracts.

The $20 \mu \mathrm{L}$ of MTS solution (Promega, USA) was added to each of the 96 well-plates after $72 \mathrm{~h}$. Then, the cells were incubated in the incubator for $4 \mathrm{~h}$. The antiproliferative activities were obtained by measuring the cells viability at an absorbance of $490 \mathrm{~nm}$ using a microplate reader (OMEGA BMG Labtech, Malaysia). The treatment was repeated in triplicate and the cell viability was calculated using the following formula: Cell viability (\%) = Absorbance (Treated cells - Untreated cells)/Absorbance (Untreated cells - Untreated cells) $\times 100 \%$. The values are expressed as the mean \pm standard deviation (SD). The half-maximal inhibitory concentration $\left(\mathrm{IC}_{50}\right)$ of both cells were determined.

\subsection{Selectivity Index (SI)}

As described by Robertson et al. (2003), the SI value was calculated using the subsequent equation: $\mathrm{SI}=\mathrm{IC}_{50}$ of MCF $10 \mathrm{~A} / \mathrm{IC} \mathrm{F}_{50}$ of MCF7. The extract with the highest SI value was selected for further analysis. The most effective extract, with the greatest antiproliferative effect on MCF7 cancer cells, was used in an additional cell viability assay with incubation periods that were varied $(24,48$, and $72 \mathrm{~h})$.

\subsection{Cell morphology of MCF7}

The MCF7 cells $\left(7.5 \times 10^{4}\right.$ cells $\left./ \mathrm{mL}\right)$ were cultured in a 6-well plate and allowed to grow in a complete medium for $24 \mathrm{~h}$. The dose concentrations of $\mathrm{IC}_{50}$ from the selected extract and the positive control, tamoxifen, were subsequently transferred to MCF7 cells and incubated for $72 \mathrm{~h}$. Then, the cells were stained with acridine orange/propidium iodide (AO/PI) dual-fluorescence dye (Sigma Aldrich, USA) (10 $\mu \mathrm{g} / \mathrm{mL})$ and incubated for 15 mins. Afterwards, 1 $\mathrm{mL}$ of PBS was added to each well twice to wash the stained cells. Finally, an inverted fluorescence microscope (Olympus, USA) was used to capture the cell morphology of the stained MCF7 cells at 40x magnification.

\subsection{Apoptosis analysis}

Briefly, the MCF7 cells $\left(2 \times 10^{5}\right.$ cells $\left./ \mathrm{mL}\right)$ were cultured in a $25 \mathrm{~cm}^{2}$ culture flask at $24 \mathrm{~h}$. The dose concentration of the IC $\mathrm{C}_{50}$ of the selected extract and tamoxifen were added to the flask. The MCF7 cells were treated for $72 \mathrm{~h}$. The apoptotic effect was carried out at $1 \times 10^{5}$ cells $/ \mathrm{mL}$ cell density. Annexin $\mathrm{V}$ FITC kit (Miltenyi Biotec, Germany) were used to evaluated the apoptotic effect of treated cells. The apoptosis effect was analysed using a flow cytometer (Moflo XDP Cell Sorter, Beckman Coulter, USA).

\subsection{Western blot}

The MCF7 cells with a density of $7.5 \times 10^{5} \mathrm{cells} / \mathrm{mL}$ were grown in the $75 \mathrm{~cm}^{2}$ culture flasks for $24 \mathrm{~h}$. The IC $\mathrm{C}_{50}$ of the selected extract and tamoxifen were used to treat the cells for $72 \mathrm{~h}$. The old media was decanted after treatment, and the attached cells were washed with cold PBS. The radioimmunoprecipitation assay (RIPA) buffer with $1 \%$ protease inhibitor cocktail (Cell Signaling Technology, USA) were used to extract protein from MCF7 cells. The $12 \%$ sodium dodecyl sulphate polyacrylamide gel electrophoresis (SDS-PAGE) was used to separate the protein according to its molecular weight. Then, the protein bands were transferred to a polyvinylidene fluoride (PVDF) membrane (Axon Scientific, Malaysia). The 5\% blocking buffer (skimmed milk) (SunLac, Malaysia) was used to block the PVDF membrane for $1 \mathrm{~h}$. Then, the PVDF membrane was washed with Tris-buffered saline with $0.1 \%$ Tween 20 detergent (TBST). The membrane was washed for 10 mins with gentle agitation four times. The membrane was blotted with diluted primary antibodies overnight at $4^{\circ} \mathrm{C}$. The primary antibodies were $\beta$-actin (PA1-183), BID (PA5-29159) and BCL-2 (PA5-20068) were obtained from

Page $3 / 16$ 
Invitrogen, USA and P53 (ab1431), BAX (ab7977), caspase-9 (ab25758), caspase-3 (ab13847) and caspase-8 (ab25901) were obtained from Abcam, UK. The next day, the PVDF membrane was rinsed four times with TBST. Anti-rabbit IgG, horseradish peroxidase-linked antibody (7074) (Cell Signaling Technology, USA) was used as a secondary antibody to blot the membrane for $1 \mathrm{~h}$. In order to determine the targeted proteins, the enhanced chemiluminescence (ECL) clarity reagent (Bio-Rad, USA) was added to the blotted membrane and eventually the protein bands were captured by the Versa Doc Imaging System (Bio-rad, USA). The ImageJ was used to analyse the band intensities and fold changes (Rueden et al. 2017). The following calculation was made using the equations: Normalized band intensity = band intensity of target protein $\div$ band intensity of $\beta$-actin

\subsection{RT-PCR}

The MCF7 cells with a concentration of $2 \times 10^{5}$ cells $/ \mathrm{mL}$ were cultured in the $25 \mathrm{~cm}^{2}$ culture flasks for $24 \mathrm{~h}$. The cells were treated for $72 \mathrm{~h}$ with the IC $\mathrm{C}_{50}$ of the selected extract and tamoxifen. After treatment, the ribonucleic acid (RNA) was isolated using the RNeasy Mini Kit (Promega, USA). The purity of RNA was measured using a Nanodrop® ND100 spectrophotometer (Thermo Fisher Scientific, USA). The complementary DNA (cDNA) was synthesised according to the Tetro ${ }^{\text {TM }}$ CDNA Synthesis kit (Meridian Bioscience, USA). The SensiFAST ${ }^{\mathrm{TM}}$ SYBRß Hi-ROX kit (Meridian Bioscience, USA) was used to determine the expression of $P 53, B I D, B C L-2, B A X$, caspase-9, caspase- 3 and caspase- 8 genes in treated MCF7 cells. The $\beta$-actin gene was used as an internal control. The gene sequences obtained from De et al. (2019), Devarajan et al. (2002), Ferreira and Cronjé (2012), Quispe-Soto et al. (2016) and Baharara et al. (2015) were presented in Table S1. The final volume of each reaction mixture was $10 \mu \mathrm{L}$, comprised of $5 \mu \mathrm{L}$ of $2 x$ SensiFAST SYBRß HiROX Mix, $1 \mu \mathrm{L}$ of synthesised cDNA (10 ng/ $\mu \mathrm{L}), 1 \mu \mathrm{L}$ of reverse and forward primers of each gene $(10 \mu \mathrm{M})$ and $3.2 \mu \mathrm{L}$ of sterile distilled water. The reaction for each gene was biologically repeated three times. The StepOne Plus ${ }^{\mathrm{TM}}$ Real-Time PCR System instrument (Applied BioSystems, USA) was set up to run under the following program: an initial denaturation step at $95^{\circ} \mathrm{C}$ for 2 mins followed by 40 cycles at $95^{\circ} \mathrm{C}$ for $5 \mathrm{~s}, 60^{\circ} \mathrm{C}$ for $5 \mathrm{~s}$, and $72^{\circ} \mathrm{C}$ for 20 s. The gene expression was measured using comparative CT $(\triangle \Delta \mathrm{CT})$ to obtain the fold change of targeted genes between the treated and untreated MCF7 cells.

\subsection{LC-QTOF-MS}

The $5 \mathrm{mg} / \mathrm{mL}$ of selected extract was mixed in $1 \mathrm{~mL}$ of methanol and filtered using a $0.45 \mu \mathrm{M}$ polytetrafluoroethylene filter. Then, the extract was conducted using an Agilent 1290 LC-QTOF-MS system consisting of an Agilent 1290 Infinity liquid chromatography system with the 6520 Accurate Mass Quadrupole Time of Flight mass spectrometer (Agilent Technologies, Santa Clara, CA, USA). The LC separations were conducted using an Agilent Zorbax Eclipse XDB-C18 column $(2.1 \times 150 \mathrm{~mm}, 3.5 \mu \mathrm{m})$ at $25^{\circ} \mathrm{C}$. The mobile phase consisted of $0.1 \%$ formic acid in water (phase A) and $0.1 \%$ formic acid in acetonitrile (phase B) was used. The parameters included: fragmentor voltage, $125 \mathrm{~V}, \mathrm{~N}_{2}$ gas flow rate, nebulizer, 45 psig and $10 \mathrm{~L} / \mathrm{min}$; $\mathrm{N}_{2}$ temperature, $300^{\circ} \mathrm{C}$. The mass range in positive modes was recorded between m/z 100 and 3200 . Additionally, the mass spectra for Agilent MassHunter Qualitative Analysis have been sorted out with an add-in to the METLIN database. The correct elemental composition structure has been produced with an accurate $\mathrm{m} / \mathrm{z}$ for compound identification (Agilent Technologies, Santa Clara, CA, USA) (Sana et al. 2008).

\subsection{Statistical analysis}

For statistical computing, the statistical analysis was carried out using PRISM Graph Pad version 8.0. Analysis of variance (ANOVA) was used to calculate the significance of differences through comparison of the mean values. The p-value of less than 0.05 was statistically significant.

\section{Results}

\subsection{Column chromatography of CN-Dcm extract}

The percentage yield of subfractionated extracts were measured based on the weight of the CN-Dcm fraction extract. Table 1 shows the extraction yield of subfraction extracts (SF1 to SF9) obtained from the CN-Dcm fraction extract. 
Table 1

Percentage yield of sub fraction extracts from $\mathrm{CN}-\mathrm{Dcm}$ extract.

\begin{tabular}{|llll|}
\hline Name of extract & Solvent system & Yield of extract $(\mathbf{g})$ & Percentage yield (\%) \\
\hline SF1 & $1: 0$ and $9: 1$ & $1.56 \pm 0.21$ & $3.11 \pm 0.25$ \\
\hline SF2 & $4: 1$ and $7: 3$ & $1.52 \pm 0.32$ & $3.03 \pm 0.45$ \\
SF3 & $3: 2$ and $1: 1$ & $1.75 \pm 0.51$ & $3.50 \pm 0.62$ \\
\hline SF4 & $2: 3$ & $1.27 \pm 0.15$ & $2.54 \pm 0.84$ \\
\hline SF5 & $3: 7$ and $1: 4$ & $1.30 \pm 0.54$ & $2.60 \pm 0.51$ \\
\hline SF6 & $1: 9$ and $0: 1$ & $1.18 \pm 0.74$ & $2.35 \pm 0.75$ \\
\hline SF7 & $1: 0$ and $9: 1$ & $1.20 \pm 0.85$ & $2.39 \pm 0.85$ \\
\hline SF8 & $3: 7$ and $2: 3$ & $0.88 \pm 0.67$ & $1.76 \pm 0.48$ \\
\hline SF9 & $3: 2$ and $1: 1$ & $1.25 \pm 0.53$ & $2.49 \pm 0.49$ \\
\hline The data represent mean \pm SD, $n=3$. & & \\
\hline
\end{tabular}

\subsection{Antiproliferative effect of subfraction extracts}

We evaluated the antiproliferative activities of subfraction extracts towards MCF7 cells and normal breast, MCF $10 \mathrm{~A}$ cells at $72 \mathrm{~h}$. The cell viabilities of treated MCF7 shown in Fig. 2 (a). The strongest inhibitory effect of MCF7 cells was SF2 extract with lowest IC $50=23.51 \pm 0.99 \mu \mathrm{g} / \mathrm{mL}$ followed by SF1 $\left(\mathrm{IC}_{50}=71.47 \pm 3.88 \mu \mathrm{g} / \mathrm{mL}\right), \mathrm{SF} 8\left(\mathrm{IC}_{50}=76.37 \pm 2.49 \mu \mathrm{g} / \mathrm{mL}\right), \mathrm{SF} 7\left(\mathrm{IC}_{50}=101.156 \pm 7.04 \mu \mathrm{g} / \mathrm{mL}\right), \mathrm{SF} 4\left(\mathrm{IC}{ }_{50}=154.05 \pm 10.04 \mu \mathrm{g} / \mathrm{mL}\right), \mathrm{SF} 6\left(\mathrm{IC}_{50}=162.11\right.$ $\pm 9.00 \mu \mathrm{g} / \mathrm{mL}), \mathrm{SF} 3\left(\mathrm{IC}_{50}=174.18 \pm 6.22 \mu \mathrm{g} / \mathrm{mL}\right), \mathrm{SF} 5\left(\mathrm{IC}_{50}=186.67 \pm 7.40 \mu \mathrm{g} / \mathrm{mL}\right), \mathrm{SF} 9\left(\mathrm{IC}_{50}=189.67 \pm 8.35 \mu \mathrm{g} / \mathrm{mL}\right)(\mathrm{Fig} .2(\mathrm{~b}))$.

The cell viability of treated MCF $10 \mathrm{~A}$ cells and their $\mathrm{IC}_{50}$ values at $72 \mathrm{~h}$ were shown in Fig. 2 (c) and (d), respectively. SF3 extract inhibited MCF $10 \mathrm{~A}$ proliferation with the lowest IC $\mathrm{I}_{50}$ value of $331.67 \pm 7.95 \mu \mathrm{g} / \mathrm{mL}$ compared to SF5 $\left(\mathrm{IC}_{50}=339.04 \pm 15.65 \mu \mathrm{g} / \mathrm{mL}\right), \mathrm{SF} 1\left(\mathrm{IC}{ }_{50}=361.55 \pm 20.56 \mu \mathrm{g} / \mathrm{mL}\right), \mathrm{SF} 4$ $\left(I_{50}=381.93 \pm 13.48 \mu \mathrm{g} / \mathrm{mL}\right), \mathrm{SF} 8\left(\mathrm{IC}_{50}=386.69 \pm 8.02 \mu \mathrm{g} / \mathrm{mL}\right), \mathrm{SF} 6\left(\mathrm{IC}_{50}=394.28 \pm 32.49 \mu \mathrm{g} / \mathrm{mL}\right), \mathrm{SF} 7\left(\mathrm{IC}_{50}=440.39 \pm 25.16 \mu \mathrm{g} / \mathrm{mL}\right), \mathrm{SF} 2\left(\mathrm{IC}_{50}=\right.$ $481.90 \pm 66.02 \mu \mathrm{g} / \mathrm{mL})$ and SF9 $\left(\mathrm{IC}_{50}=669.59 \pm 40.82 \mu \mathrm{g} / \mathrm{mL}\right.$. Based on Fig. $2(\mathrm{e})$, the SI value showed that the SF2 extract was the most selective subfraction extract with SI value of $20.46 \pm 2.24$.

The cells viability assay of SF2-treated MCF7 was conducted using different time interval $(24,48$, and $72 \mathrm{~h})$ to ensure that the lowest dose concentration was attained at $72 \mathrm{~h}$ and the inhibitory effect of SF2 extract occurred in a dose- and time-dependent manner. Fig. 3 (a) and (b) show the inhibitory effects and the $\mathrm{IC}_{50}$ values for the three different time intervals, respectively. SF2 extract inhibited half maximal of MCF7 cell proliferation at a concentration of $66.48 \pm 3.69 \mu \mathrm{g} / \mathrm{mL}$ at $24 \mathrm{~h}$, whereas at $48 \mathrm{~h}$, the SF2 extract's IC $\mathrm{I}_{50}$ was $51.85 \pm 1.78 \mu \mathrm{g} / \mathrm{mL}$ at $72 \mathrm{~h}$, the IC 50 value was $23.51 \pm 0.99 \mu \mathrm{g} / \mathrm{mL}$. The IC $\mathrm{I}_{50}$ value of the SF2 extract decreased when the incubation time increased. Tamoxifen was used as a positive control. Fig. 3 (c) and (d) show the cell viabilities of MCF7 cancer cells against tamoxifen treatment and their $\mathrm{IC}_{50}$ values at 24,48 and $72 \mathrm{~h}$, respectively. The IC 50 values of tamoxifen against MCF7 cells were $3.61 \pm 0.29 \mu \mathrm{g} / \mathrm{mL}(9.72 \pm 0.78 \mu \mathrm{M}), 1.49 \pm 0.07 \mu \mathrm{g} / \mathrm{mL}(4.02 \pm 0.19 \mu \mathrm{M}), 1.31 \pm 0.04 \mu \mathrm{g} / \mathrm{mL}(3.52 \pm 0.11 \mu \mathrm{M})$ at 24,48 and $72 \mathrm{~h}$, respectively. Based on the findings, the $\mathrm{IC}_{50}$ values of SF2 extract and tamoxifen at $72 \mathrm{~h}$ incubation were used in subsequent experiments.

\subsection{Cell morphological analysis}

The AO/PI fluorescent dye was used to evaluate the cell morphology of untreated control and treated MCF7 cells. Fig. 4 (a) displays the untreated control MCF7 cells, where the cells had circular nuclei which were still intact and exhibited in green coloured. Fig. 4 (b) and (c) show the cell morphology of the MCF7 cells treated with SF2 extract and tamoxifen, respectively. At early apoptotic stage, the MCF7 cells exhibited greenish-yellow with orange-coloured nuclei. As cells progress to late apoptosis, the cells lose their green colour and turn red-orange. The fluorescence staining of MCF7 cells using AO/PI dye showed that the MCF7 cells had membrane blebbing which clearly demonstrated the apoptotic properties.

\subsection{Apoptosis effect}

Figure 5 displays the results of flow cytometry analysis of untreated and treated MCF7 cells at $72 \mathrm{~h}$. Figure 5 (a) shows that the live cells of untreated MCF7 cells had a higher percentage value of $95.52 \pm 0.71 \%$, which was almost $100 \%$ of cell viability. Figure 5 (b) and (c) also showed that the treated MCF7 cells showed approximately $50 \%$ of live cells (SF2 $=55.13 \pm 5.34 \%$ and tamoxifen $=48.79 \pm 1.73 \%$ ) at 72 h. Meanwhile, the dead cells of untreated and treated cells were less than $1 \%$. Based on Figure 5 (d), the induction of early cell apoptosis treated with SF2 extract ( $26.73 \pm 0.99 \%)$ showed significant differences from Tamoxifen $(37.40 \pm 1.60 \%)$. The percentage of late apoptosis in MCF7 cells treated with SF2 extract did not differ significantly from tamoxifen, with $17.54 \pm 2.55 \%$ and $13.47 \pm 1.17 \%$, respectively.

\subsection{Western blot}

Through western blot, the apoptosis-inducing effects of the MCF7 cell treatment were examined after $72 \mathrm{~h}$. The death receptor protein (P53), BCL-2 apoptotic family proteins (BAX, BID and BCL-2) and caspase family (caspase-9, caspase-8, and caspase-3) were used as the targeted apoptosis proteins 
while $\beta$-actin was used as a loading control. As shown in Fig. 6, SF2 and tamoxifen treatment increased P53 by $1.68 \pm 0.07$ and $1.79 \pm 0.04$, respectively, as compared to untreated MCF7 cancer cells. BAX protein expression was $2.44 \pm 0.08$-fold higher in SF2-treated MCF7 cells than in tamoxifen, which was $1.97 \pm 0.08$-fold higher. BCL-2 protein expression was down-regulated in MCF7 cancer cells treated with SF2 extract and tamoxifen, with fold changes of $0.21 \pm 0.07$ and $0.43 \pm 0.06$, respectively. The expression level of BID increased by $1.72 \pm 0.14$ in SF2 treatment. However, BID expression in tamoxifen treatment had no significant different when compared to untreated MCF7 cells. Furthermore, the findings showed increased expression in the caspase family. Caspase-8 protein expression was upregulated in treated MCF7 cells (SF2 $=1.33 \pm 0.09$ and tamoxifen $=1.23 \pm 0.05$ ) and caspase-3 protein expression resulted in $2.75 \pm 0.25$ in SF2 treatment. Moreover, the expression of caspase- 9 was significantly up-regulated in treated MCF7 cells (SF2 = $3.10 \pm 0.20$ and tamoxifen $=1.87 \pm 0.10$ ). The western blot analysis revealed that SF2 treatment increased the BAX, caspase-9 and caspase-3 expression in MCF7 cells significantly more than tamoxifen treatment.

\subsection{RT-PCR}

By using qualitative RT-PCR, the targeted gene expression from untreated and treated MCF7 cells were validated (Fig. 7). For positive control, tamoxifen, the treated MCF7 cells exhibited upregulated expression of $P 53(1.63 \pm 0.03), B A X(1.69 \pm 0.08), B I D(1.27 \pm 0.16)$, caspase-8 (1.42 \pm 0.15$)$, caspase-9 $(1.63 \pm 0.31)$ and caspase-3 $(1.40 \pm 0.15)$ and downregulated expression of $B C L-2(0.78 \pm 0.11)$ compared to untreated control MCF7 cells. According to the analysis, expression of BID did not vary significantly between untreated MCF7 cells and positive control sample. Nonetheless, all gene expressions in SF2 treatment showed significant differences when compared to the untreated MCF7 cells with $\mathrm{p}<0.05$. The SF2-treated MCF7 cells demonstrated upregulated expression of $P 53(1.54 \pm 0.15), B A X(2.41 \pm 0.12), B I D(1.88 \pm 0.12)$, caspase-8 (1.29 \pm 0.12$)$, caspase-9 (3.02 \pm 0.47$)$ and caspase-3 (2.63 \pm $0.15)$ (Fig. 8). Additionally, the SF2-treated MCF7 cells downregulated the expression level of $B C L-2(0.47 \pm 0.10)$. Interestingly, the gene expression analysis by RT-qPCR clearly validated the protein expression analysis by western blot. Despite the fact that SF2 extract expressed all of the targeted apoptosis pathway expressions, the outcomes demonstrated that SF2 extract provided better apoptotic effect in MCF7 by up-regulating BAX, caspase-9, and caspase-3 protein expressions.

\subsection{LC-QTOF-MS}

To qualitatively investigate the compounds found in SF2 extract, the identification was carried out by comparing mass error between theoretical mass and mass observed data obtained. A mass screening on the above spectrum was conducted and summarised in Table 2. Using LC-QTOF-MS analysis, 23 compounds found in the SF2 extract, with 24 peaks were detected (Fig. S2). Dihydrojasmonic acid, methyl ester was presented between the two peaks of the SF2 extract peak chromatogram. 
Table 2

Chemical compounds found in SF2 extract using LC-QTOF-MS analysis.

\begin{tabular}{|c|c|c|c|c|c|c|c|c|c|c|c|}
\hline No. & Proposed Compounds & Formula & RT & $\begin{array}{l}\text { Observed } \\
(\mathrm{m} / \mathrm{z})\end{array}$ & $\begin{array}{l}\text { Theoretical } \\
(\mathrm{m} / \mathrm{z})\end{array}$ & $\begin{array}{l}\text { Score } \\
\text { (DB) }\end{array}$ & $\begin{array}{l}\text { Score } \\
\text { (MFG) }\end{array}$ & $\begin{array}{l}\text { Diff } \\
\text { (DB, } \\
\text { ppm) }\end{array}$ & $\begin{array}{l}\text { Diff } \\
\text { (MFG, } \\
\text { ppm) }\end{array}$ & $\begin{array}{l}\text { Adducts } \\
\text { ions }\end{array}$ & TFF \\
\hline 1 & Furfural diethyl acetal & $\mathrm{C}_{9} \mathrm{H}_{14} \mathrm{O}_{3}$ & 8.261 & 171.1011 & 170.0938 & 98.45 & 98.45 & 2.62 & 2.62 & $(\mathrm{M}+\mathrm{H})+$ & 6 \\
\hline 2 & $\begin{array}{l}\text { 4-(2-hydroxypropoxy)-3,5- } \\
\text { dimethyl-phenol }\end{array}$ & $\mathrm{C}_{11} \mathrm{H}_{16} \mathrm{O}_{3}$ & 9.087 & 197.1176 & 196.1102 & 98.43 & 98.43 & -1.12 & -1.11 & $(\mathrm{M}+\mathrm{H})+$ & 10 \\
\hline 3 & $\begin{array}{l}\text { N-Butyl-1H-pyrazolo[3,4- } \\
\text { d]pyrimidin-4-amine }\end{array}$ & $\mathrm{C}_{9} \mathrm{H}_{13} \mathrm{~N}_{5}$ & 10.515 & 209.1506 & 191.1169 & 84.43 & 84.45 & 1.08 & 1.09 & $(\mathrm{M}+\mathrm{NH} 4+$ & 2 \\
\hline 4 & $\begin{array}{l}\text { 8S-hydroxy-2-Decene-4,6-diynoic } \\
\text { acid }\end{array}$ & $\mathrm{C}_{10} \mathrm{H}_{10} \mathrm{O}_{3}$ & 10.870 & 179.0701 & 178.0627 & 86.24 & 86.24 & 1.55 & 1.55 & $(\mathrm{M}+\mathrm{H})+$ & 2 \\
\hline 5 & 3-tert-Butyl-5-methylcatechol & $\mathrm{C}_{11} \mathrm{H}_{16} \mathrm{O}_{2}$ & 12.122 & 181.1220 & 180.1146 & 96.71 & 96.72 & 2.6 & 2.6 & $(\mathrm{M}+\mathrm{H})+$ & 6 \\
\hline 6 & 2,6-Nonadien-1-ol & $\mathrm{C}_{9} \mathrm{H}_{16} \mathrm{O}$ & 12.314 & 158.1541 & 140.1201 & 97.61 & 97.61 & -0.12 & -0.12 & $(\mathrm{M}+\mathrm{NH} 4)+$ & 3 \\
\hline 7 & $\begin{array}{l}\text { 12-oxo-5E,8E,10Z- } \\
\text { dodecatrienoic acid }\end{array}$ & $\mathrm{C}_{12} \mathrm{H}_{16} \mathrm{O}_{3}$ & 12.748 & 209.1163 & 208.1089 & 81.51 & 81.53 & 4.92 & 4.92 & $(\mathrm{M}+\mathrm{H})+$ & 2 \\
\hline 8 & $\begin{array}{l}\text { 2-[2-(4-Pyridinyl)-1- } \\
\text { butenyl]phenol }\end{array}$ & $\mathrm{C}_{15} \mathrm{H}_{15} \mathrm{NO}$ & 13.150 & 226.1217 & 225.1147 & 92.94 & 92.95 & 2.79 & 2.79 & $(\mathrm{M}+\mathrm{H})+$ & 4 \\
\hline 9 & 4-Vinylcyclohexene dioxide & $\mathrm{C}_{8} \mathrm{H}_{12} \mathrm{O}_{2}$ & 13.264 & 163.0731 & 140.0839 & 86.47 & 86.5 & -1.27 & -1.28 & $(\mathrm{M}+\mathrm{Na})+$ & 2 \\
\hline 10 & $\begin{array}{l}\text { 2,2,4,4,-Tetramethyl-6-(1- } \\
\text { oxopropyl)-1,3,5- } \\
\text { cyclohexanetrione }\end{array}$ & $\mathrm{C}_{13} \mathrm{H}_{18} \mathrm{O}_{4}$ & 13.465 & 239.1269 & 238.1199 & 81.29 & 81.3 & 2.65 & 2.65 & $(\mathrm{M}+\mathrm{H})+$ & 2 \\
\hline 11 & $\begin{array}{l}\text { Estra-1,3,5(10)-triene- } \\
\text { 3,6alpha,17beta-triol triacetate }\end{array}$ & $\mathrm{C}_{24} \mathrm{H}_{30} \mathrm{O}_{6}$ & 13.942 & 415.2099 & 414.2025 & 92.29 & 92.3 & 4.1 & 4.1 & $(\mathrm{M}+\mathrm{H})+$ & 10 \\
\hline 12 & $\begin{array}{l}\text { 7b- } \\
\text { Hydroxydehydroepiandrosterone }\end{array}$ & $\mathrm{C}_{19} \mathrm{H}_{28} \mathrm{O}_{3}$ & 14.457 & 305.2104 & 304.2031 & 82.38 & 82.34 & 2.48 & 2.48 & $(\mathrm{M}+\mathrm{H})+$ & 2 \\
\hline 13 & $\begin{array}{l}5 Z, 8 Z, 11 Z, 14 Z- \\
\text { octadecatetraenoic acid }\end{array}$ & $\mathrm{C}_{18} \mathrm{H}_{28} \mathrm{O}_{2}$ & 14.854 & 277.2171 & 276.2096 & 96.04 & 96.04 & -2.52 & -2.52 & $(\mathrm{M}+\mathrm{H})+$ & 7 \\
\hline 14 & $\begin{array}{l}\text { (9S,13S)-1a,1b-dihomo- } \\
\text { jasmonic acid }\end{array}$ & $\mathrm{C}_{14} \mathrm{H}_{22} \mathrm{O}_{3}$ & 14.873 & 239.1644 & 238.157 & 86.02 & 86.03 & -0.64 & -0.64 & $(\mathrm{M}+\mathrm{H})+$ & 2 \\
\hline 15 & $\begin{array}{l}\text { Dihydrojasmonic Acid, Methyl } \\
\text { Ester }\end{array}$ & $\mathrm{C}_{13} \mathrm{H}_{22} \mathrm{O}_{3}$ & 15.627 & 227.1639 & 226.1564 & 95.18 & 95.18 & 2.37 & 2.37 & $(\mathrm{M}+\mathrm{H})+$ & 3 \\
\hline 16 & 5-methyl-octanoic acid & $\mathrm{C}_{9} \mathrm{H}_{18} \mathrm{O}_{2}$ & 15.792 & 181.1198 & 158.1305 & 92.94 & 92.96 & 1.08 & 1.08 & $(\mathrm{M}+\mathrm{Na})+$ & 3 \\
\hline 17 & $\begin{array}{l}\text { Methyl 15,16-epoxy-9,12- } \\
\text { octadecadienoate }\end{array}$ & $\mathrm{C}_{19} \mathrm{H}_{32} \mathrm{O}_{3}$ & 16.234 & 309.2427 & 308.2339 & 70.22 & 70.23 & 3.96 & 3.96 & $(\mathrm{M}+\mathrm{H})+$ & 4 \\
\hline 18 & $\begin{array}{l}\text { Dihydrojasmonic Acid, Methyl } \\
\text { Ester }\end{array}$ & $\mathrm{C}_{13} \mathrm{H}_{22} \mathrm{O}_{3}$ & 16.420 & 227.1639 & 226.1568 & 97.12 & 97.12 & 0.58 & 0.58 & $(\mathrm{M}+\mathrm{H})+$ & 3 \\
\hline 19 & $\begin{array}{l}\text { 1-(2-Hydroxyethyl)-2- } \\
\text { hydroxymethyl-5-nitroimidazole }\end{array}$ & $\mathrm{C}_{6} \mathrm{H}_{9} \mathrm{~N}_{3} \mathrm{O}_{4}$ & 16.706 & 205.0929 & 187.0591 & 93.64 & 93.65 & 0.87 & 0.87 & $(\mathrm{M}+\mathrm{NH} 4)+$ & 4 \\
\hline 20 & $( \pm)$ 8-Gingerol & $\mathrm{C}_{19} \mathrm{H}_{30} \mathrm{O}_{4}$ & 16.786 & 323.2229 & 322.2155 & 80.94 & 81.18 & -3.24 & -3.24 & $(\mathrm{M}+\mathrm{H})+$ & 5 \\
\hline 21 & Jasmolin I & $\mathrm{C}_{21} \mathrm{H}_{30} \mathrm{O}_{3}$ & 17.068 & 331.2262 & 330.219 & 97.52 & 97.51 & 1.65 & 1.65 & $(\mathrm{M}+\mathrm{H})+$ & 4 \\
\hline 22 & $\begin{array}{l}\text { 9,10,16-Trihydroxyhexadecanoic } \\
\text { acid }\end{array}$ & $\mathrm{C}_{16} \mathrm{H}_{32} \mathrm{O}_{5}$ & 17.516 & 307.2321 & 306.225 & 88.47 & 88.47 & 3.96 & 3.96 & $(\mathrm{M}+\mathrm{H})+$ & 4 \\
\hline 23 & (+)-Epicatechin & $\mathrm{C}_{15} \mathrm{H}_{14} \mathrm{O}_{6}$ & 17.764 & 293.2503 & 292.2431 & 82.63 & 82.63 & 5.59 & 5.59 & $(\mathrm{M}+\mathrm{H})+$ & 4 \\
\hline 24 & 17(R)-Resolvin D1 & $\mathrm{C}_{22} \mathrm{H}_{32} \mathrm{O}_{5}$ & 19.406 & 377.2322 & 376.2241 & 73.47 & 73.48 & 2.45 & 2.45 & $(\mathrm{M}+\mathrm{H})+$ & 8 \\
\hline
\end{tabular}

\section{Discussion}

C. nutans is one of the medicinal plants that may offer anticancer properties (Kamarudin et al. 2017). Nevertheless, the effectiveness of plant bioactivity will vary with the process and the solvent chosen for plant extraction. While it is important to utilise suitable solvents, it is also important to note that the solvent polarity will affect how the extract separates (Majeed et al. 2016). In this study, we subfractionated the CN-Dcm extract using the column 
chromatography based on different solvent systems. The extraction results revealed that the $\mathrm{R}_{\mathrm{f}}$ value between the extracts were distinct. According to Dai and Mumper (2010), the choice of the solvent mixtures could give higher layers of separation. Therefore, this method was done to diminish unwanted interference and to increase the purity of active extracts.

Yaacob et al. (2010) reported that the subfractionation extracts of Strobilanthes crispus using column chromatography had greater potential in inhibiting cancer cells, which corroborated with the current study that showed SF2 extract had a strong inhibitory effect against MCF7 cancer cells proliferation compared to crude and fraction extract of $C$. nutans leaves from previous study (Ismail et al. 2020). The SF2 extract displayed the lowest IC 50 value which followed the National Cancer Institute ( $\mathrm{NCl}$ ) guidelines, which state that the plant extracts should have an $\mathrm{IC}_{50}<30 \mu \mathrm{g} / \mathrm{mL}(\mathrm{Fadeyi}$ et al. 2013 ). When compared to the $\mathrm{IC}_{50}$ values of treated MCF7 cells at $72 \mathrm{~h}$, we may conclude that our subfraction extracts were not extremely cytotoxic towards MCF $10 \mathrm{~A}$ cells. The findings demonstrated that the $\mathrm{IC}_{50}$ of subfraction extracts had to be larger than $300 \mu \mathrm{g} / \mathrm{mL}$ to inhibit MCF $10 \mathrm{~A}$ cells. According to Khazaei et al. (2017) and Prayong et al. (2008), the SI value of more than two suggests that the extract is deemed to be safer and has high selectivity. All subfraction extracts except SF3 and SF5 had SI values of more than two while SF2 extract having the highest SI value.

The cell morphology of SF2-treated MCF7 cells stained with AO/PI dye suggested that SF2 extract triggered cell death in MCF7 cancer cells. The apoptotic effect of SF2-treated MCF7 cells was in line with studies of other medicinal plants such as Moringa oleifera (Mohd Fisall et al. 2021), Boswellia dalzielii (Adebayo et al. 2020), Christia vespertilionis (Ismail et al. 2021b), Garcinia atroviridis (Zulkifli et al., 2020) and Allium atroviolaceum (Khazaei et al. 2017). Our findings suggest that SF2 extract may have apoptosis-inducing effects. The proteins and genes expression have been studied to elucidate the mechanisms for the apoptosis activation on treated MCF7 cells. The results revealed that P53-mediated apoptosis were expressed in the SF2-treated MCF7 cells. P53 has a significant impact on apoptosis and cell cycle regulations (Ozaki and Nakagawara 2011). Interestingly, P53 able to bind with BAX to regulate the apoptosis process (Fridman and Lowe 2003).

For SF2-treated MCF7 cells, the decreased in BCL-2 and increased in BAX expression promotes apoptosis activation. BCL-2 may disrupt the BAX oligomerisation when the level of BCL-2 is raising (Chipuk and Green 2008). In this study, the release of BAX was caused by a decrease in BCL-2 levels which may have activated the intrinsic apoptosis pathway. BAX involved in the pores of the mitochondrial membrane, which caused cytochrome $C$ released and ultimately caspase-9 was activated (Korsmeyer et al. 2000). Importantly, the SF2 extract induced BCL-2 downregulation which corroborates with other C. nutans studies that revealed suppression of BCL-2 level (Hii et al. 2019; Nik Zainuddin et al. 2019; Wang et al. 2019). The activation of caspase-8 can lead to the breakage of the BID, the BCL-2 family protein with $\mathrm{BH} 3$ domain, and then to the mitochondria translocating the cytochrome $\mathrm{C}$ release. BID indicate a connection between the extrinsic and intrinsic apoptotic signaling pathways. (Los and Gibson 2005; Maximov and Maximov 2008). Furthermore, upregulation of caspase- 9 and caspase-8 in MCF7 cells demonstrated that SF2 extract was effective in initiating both the intrinsic and extrinsic apoptosis signalling pathways. This could be an explanation for the upregulation of caspase-3 at the final stage of apoptosis (Liu et al. 2015).

Based on LC-QTOF-MS analysis, 1-(2-Hydroxyethyl)-2-hydroxymethyl-5-nitroimidazole has anti-microbial activity (Starek et al. 2021). Moreover, 17(R)Resolvin D1 has anti-inflammatory activity and can control Toll-like receptor4-mediated inflammatory responses of human macrophages to lipopolysaccharide and Escherichia coli, according to a previous report by Palmer et al. (Palmer et al. 2011). Epicatechin has been found to lower blood glucose levels, and it has been linked to antioxidant, anticancer and antiangiogenic properties (Abdulkhaleq et al. 2017). In addition, 8Gingerol inhibited proliferation and migration of colorectal cancer (CRC) cells models through the EGFR/STAT/ERK pathway (Hu et al. 2020). Hence, the compounds from SF2 extract may also be the contributing factors for the apoptosis effect shown in MCF7 cells. There are several differences between the various phytochemical compounds observed in the C. nutans studies since the main factor influencing plants is the surrounding environment such as humidity, water, and nutrient content (Ismail et al. 2016, 2017, 2021a; Abd Samat et al. 2020). Thus, understanding these bioactive compounds and elucidating their structural features will facilitate in future drug research.

\section{Conclusion}

In conclusion, SF2 extract had a strong inhibition of cell growth and an ability to cause apoptosis in MCF7. The SF2 extract supressed the proliferation of MCF7 cells due to the BCL-2 downregulation and also activated apoptosis effect in the MCF7. Moreover, this extract caused activation of P53 death receptor and caspase family in the treated MCF7 cells. The compounds from SF2 extract appears to be a viable candidate for drug research and development. For future studies, it may be beneficial to isolate and characterize the active compound found in SF extract.

\section{Declarations}

\section{Acknowledgements}

This first author would like to thank Universiti Sains Malaysia for providing a USM Fellowship Scheme to support the work.

\section{Author contribution}

NZI and HA conceived and designed the experiment; NZI, SMS, IAA, ZMT, and RA performed the experiment; NZI and IAA writing the draft manuscript. NZI, HA, and NNMZ writing - review \& editing. All authors have read and agreed to the published version of the manuscript. 


\section{Funding}

The authors declare that no funds, grants, or other support were received during the preparation of this manuscript.

\section{Data availability}

All data generated or analysed during this study are included in this article.

\section{Ethics approval}

Not applicable.

\section{Consent to participate}

Not applicable.

\section{Consent for publication}

Not applicable.

\section{Competing interests}

The authors declare no competing interests.

\section{References}

1. Abd Samat NMA, Ahmad S, Awang Y, et al (2020) Alterations in herbage yield, antioxidant activities, phytochemical contents, and bioactive compounds of Sabah Snake Grass (Clinacanthus Nutans L.) with Regards to harvesting age and harvesting frequency. Molecules 25:1-16. https://doi.org/10.3390/molecules25122833

2. Abdulkhaleq LA, Assi MA, Noor MHM, et al (2017) Therapeutic uses of epicatechin in diabetes and cancer. Vet World 10:869-872. https://doi.org/10.14202/vetworld.2017.869-872

3. Adebayo IA, Usman Al, Shittu FB, et al (2020) Boswellia dalzielii-mediated silver nanoparticles inhibited acute myeloid leukemia (AML) Kasumi-1 cells by inducing cell cycle arrest. Bioinorg Chem Appl 2020:1-11. https://doi.org/10.1155/2020/8898360

4. Alam A, Ferdosh S, Ghafoor K, et al (2016) Clinacanthus nutans: A review of the medicinal uses, pharmacology and phytochemistry. Asian Pac J Trop Med 9:402-409. https://doi.org/10.1016/j.apjtm.2016.03.011

5. Baharara J, Namvar F, Ramezani T, et al (2015) Silver nanoparticles biosynthesized using Achillea biebersteinii flower extract: apoptosis induction in MCF-7 cells via caspase activation and regulation of Bax and Bcl-2 gene expression. Molecules 20:2693-2706

6. Britt KL, Cuzick J, Phillips KA (2020) Key steps for effective breast cancer prevention. Nat Rev Cancer 20:417-436. https://doi.org/10.1038/s41568020-0266-x

7. Chelyn JLJLL, Omar MHMHMHH, Mohd Yousof NSANSA, et al (2014) Analysis of flavone C -glycosides in the leaves of Clinacanthus nutans (Burm. f.) Lindau by HPTLC and HPLC-UV/DAD. Sci World J 2014:1-7. https://doi.org/10.1155/2014/724267

8. Chipuk JE, Green DR (2008) How do BCL-2 proteins induce mitochondrial outer membrane permeabilization? Trends Cell Biol 18:157-164. https://doi.org/10.1016/j.tcb.2008.01.007

9. Dai J, Mumper RJ (2010) Plant phenolics: extraction, analysis and their antioxidant and anticancer properties. Molecules 15:7313-7352. https://doi.org/10.3390/molecules15107313

10. De AK, Muthiyan R, Mondal S, et al (2019) A natural quinazoline derivative from marine sponge hyrtios erectus induces apoptosis of breast cancer cells via ROS production and intrinsic or extrinsic apoptosis pathways. Mar Drugs 17:1-20. https://doi.org/10.3390/md17120658

11. Devarajan E, Sahin AA, Chen JS, et al (2002) Down-regulation of caspase 3 in breast cancer: a possible mechanism for chemoresistance. Oncogene 21:8843-8851. https://doi.org/10.1038/sj.onc.1206044

12. Fadeyi SA, Fadeyi OO, Adejumo AA, et al (2013) In vitro anticancer screening of 24 locally used Nigerian medicinal plants. BMC Complement Med Ther 13:1-10. https://doi.org/10.1186/1472-6882-13-79

13. Ferreira E, Cronjé MJ (2012) Selection of suitable reference genes for quantitative real-time PCR in apoptosis-induced MCF-7 breast cancer cells. Mol Biotechnol 50:121-128. https://doi.org/10.1007/s12033-011-9425-3

14. Fridman JS, Lowe SW (2003) Control of apoptosis by p53. Oncogene 22:9030-9040. https://doi.org/10.1038/sj.onc.1207116

Page 9/16 
15. Fu B, Wang N, Tan HY, et al (2018) Multi-component herbal products in the prevention and treatment of chemotherapy-associated toxicity and side effects: A review on experimental and clinical evidences. Front Pharmacol 9:1-15

16. Greenwell M, Rahman P (2015) Medicinal plants: their use in anticancer treatment. Int J Pharm Sci Res 6:4103-4112. https://doi.org/10.13040/IJPSR.0975-8232.6(10).4103-12

17. Hii LWWL-WL-WW, Lim S-HHES-HESHE, Leong C-OOCOC-O, et al (2019) The synergism of Clinacanthus nutans Lindau extracts with gemcitabine: Downregulation of anti-apoptotic markers in squamous pancreatic ductal adenocarcinoma. BMC Complement Altern Med 19:1-13. https://doi.org/10.1186/s12906-019-2663-9

18. Hu SM, Yao XH, Hao YH, et al (2020) 8-Gingerol regulates colorectal cancer cell proliferation and migration through the EGFR/STAT/ERK pathway. Int J Oncol 56:390-397

19. Ismail NZ, Adebayo IA, Mohamad Zain NN, Arsad H (2021a) Molecular docking of compounds from Clinacanthus nutans extract detected by GC-MS analysis with the SARS-CoV-2 main protease and ACE2 protein. Nat Prod Res 1-5. https://doi.org/10.1080/14786419.2021.1919104

20. Ismail NZ, Adebayo IA, Mohamed WAS, et al (2021b) Christia vespertilionis extract induced antiproliferation and apoptosis in breast cancer (MCF7) cells. Mol Biol Rep 48:7361-7370. https://doi.org/10.1007/s11033-021-06743-w

21. Ismail NZ, Arsad H, Samian MR, et al (2018) Assessment of three plastid DNA barcode markers for identification of Clinacanthus nutans (Acanthaceae). 3 Biotech 8:1-8. https://doi.org/10.1007/s13205-018-1092-7

22. Ismail NZ, Arsad H, Samian MR, Hamdan MR (2017) Determination of phenolic and flavonoid contents, antioxidant activities and GC-MS analysis of Clinacanthus nutans (Acanthaceae) in different locations. AGRIVITA, J Agric Sci 39:335-344. https://doi.org/10.17503/agrivita.v39i3.1076

23. Ismail NZ, Md Toha Z, Muhamad M, et al (2020) Antioxidant effects, antiproliferative effects, and molecular docking of Clinacanthus nutans leaf extracts. Molecules 25:1-18. https://doi.org/10.3390/molecules25092067

24. Ismail NZNZ, Arsad H, Samian MRMR, et al (2016) Evaluation of genetic diversity of Clinacanthus nutans (Acanthaceaea) using RAPD, ISSR and RAMP markers. Physiol Mol Biol Plants 22:523-534. https://doi.org/10.1007/s12298-016-0391-x

25. Kamarudin MNA, Sarker MMR, Kadir HA, Ming LC (2017) Ethnopharmacological uses, phytochemistry, biological activities, and therapeutic applications of Clinacanthus nutans (Burm. f.) Lindau: A comprehensive review. J Ethnopharmacol 206:245-266. https://doi.org/10.1016/j.jep.2017.05.007

26. Kaur S, Pandit K, Chandel M, Kaur S (2020) Antiproliferative and apoptogenic effects of Cassia fistula L n-hexane fraction against human cervical cancer (HeLa) cells. Environ Sci Pollut Res 27:32017-32033. https://doi.org/10.1007/s11356-020-08916-9

27. Khazaei S, Abdul Hamid R, Ramachandran V, et al (2017) Cytotoxicity and proapoptotic effects of Allium atroviolaceum flower extract by modulating cell cycle arrest and caspase-dependent and p53-independent pathway in breast cancer cell lines. Evidence-Based Complement Altern Med 2017:117. https://doi.org/10.1155/2017/1468957

28. Korsmeyer SJ, Wei MC, Saito MT, et al (2000) Pro-apoptotic cascade activates BID, which oligomerizes BAK or BAX into pores that result in the release of cytochrome c. Cell Death Differ 7:1166-1173

29. Krauss K, Stickeler E (2020) Endocrine Therapy in Early Breast Cancer. Breast Care 15:337-346. https://doi.org/10.1159/000509362

30. Levenson AS, Jordan VC (1997) MCF-7: the first hormone-responsive breast cancer cell line. Cancer Res 57:3071-3078

31. Liu X, He Y, Li F, et al (2015) Caspase-3 promotes genetic instability and carcinogenesis. Mol Cell 58:284-296

32. Los M, Gibson SB (2005) Apoptotic pathways as targets for novel therapies in cancer and other diseases. Springer

33. Majeed M, Hussain Al, Chatha SAS, et al (2016) Optimization protocol for the extraction of antioxidant components from Origanum vulgare leaves using response surface methodology. Saudi J Biol Sci 23:389-396. https://doi.org/10.1016/j.sjbs.2015.04.010

34. Maximov GK, Maximov KG (2008) The role of p53 tumor-suppressor protein in apoptosis and cancerogenesis. Biotechnol Biotechnol Equip 22:664668

35. Mohd Fisall UF, Ismail NZ, Adebayo IA, Arsad H (2021) Dichloromethane fraction of Moringa oleifera leaf methanolic extract selectively inhibits breast cancer cells (MCF7) by induction of apoptosis via upregulation of Bax, p53 and caspase 8 expressions. Mol Biol Rep 1-11. https://doi.org/10.1007/s11033-021-06466-y

36. Nik Zainuddin NASNAS, Muhammad H, Nik Fakhuruddin NH, et al (2019) Semi-purified fraction of Clinacanthus nutans induced apoptosis in human cervical cancer, SiHa cells via up-regulation of Bax and down-regulation of Bcl-2. Sains Malaysiana 48:1997-2006. https://doi.org/10.17576/jsm2019-4809-21

37. Ozaki T, Nakagawara A (2011) Role of p53 in cell death and human cancers. Cancers (Basel) 3:994-1013

38. Palmer CD, Mancuso CJ, Weiss JP, et al (2011) 17 (R)-Resolvin D1 differentially regulates TLR4-mediated responses of primary human macrophages to purified LPS and live E. coli. J Leukoc Biol 90:459-470

39. Prayong P, Barusrux S, Weerapreeyakul N (2008) Cytotoxic activity screening of some indigenous Thai plants. Fitoterapia 79:598-601. https://doi.org/10.1016/j.fitote.2008.06.007

40. Quispe-Soto ET, Calaf GM (2016) Effect of curcumin and paclitaxel on breast carcinogenesis. Int J Oncol 49:2569-2577

41. Robertson JFR, Osborne CK, Howell A, et al (2003) Fulvestrant versus anastrozole for the treatment of advanced breast carcinoma in postmenopausal women: a prospective combined analysis of two multicenter trials. Cancer 98:229-238. https://doi.org/10.1002/cncr.11468

42. Rueden CT, Schindelin J, Hiner MC, et al (2017) ImageJ2: ImageJ for the next generation of scientific image data. BMC Bioinformatics 18:1-26

Page 10/16 
43. Sak K (2012) Chemotherapy and dietary phytochemical agents. Chemother Res Pract 2012:

44. Sana TR, Roark JC, Li X, et al (2008) Molecular formula and METLIN Personal Metabolite Database matching applied to the identification of compounds generated by LC/TOF-MS. J Biomol Tech 19:258-266

45. Scambia G, Ranelletti FO, Panici PB, et al (1994) Quercetin potentiates the effect of adriamycin in a multidrug-resistant MCF-7 human breast-cancer cell line: P-glycoprotein as a possible target. Cancer Chemother Pharmacol 34:459-464. https://doi.org/10.1007/BF00685655

46. Siew YY, Zareisedehizadeh S, Seetoh WG, et al (2014) Ethnobotanical survey of usage of fresh medicinal plants in Singapore. J Ethnopharmacol 155:1450-1466. https://doi.org/10.1016/j.jep.2014.07.024

47. Starek M, Dąbrowska M, Chebda J, et al (2021) Stability of Metronidazole and Its Complexes with Silver (I) Salts under Various Stress Conditions. Molecules 26:3582

48. Sung H, Ferlay J, Siegel RL, et al (2021) Global Cancer Statistics 2020: GLOBOCAN estimates of incidence and mortality worldwide for 36 cancers in 185 countries. CA Cancer J Clin 1-41. https://doi.org/10.3322/caac. 21660

49. Wang KS, Chan CK, Hidayat AFA, et al (2019) Clinacanthus nutans induced reactive oxygen species-dependent apoptosis and autophagy in HCT116 human colorectal cancer cells. Pharmacogn Mag 15:87-97. https://doi.org/10.4103/pm.pm_299_17

50. Welsh J (2013) Chapter 40-Animal Models for Studying Prevention and Treatment of Breast Cancer. Anim Model Study Hum Dis Conn, PM, Ed 997-1018

51. Yaacob NS, Hamzah N, Nik Mohamed Kamal NN, et al (2010) Anticancer activity of a sub-fraction of dichloromethane extract of Strobilanthes crispus on human breast and prostate cancer cells in vitro. BMC Complement Altern Med 10:42. https://doi.org/10.1186/1472-6882-10-42

52. Yabroff KR, Lund J, Kepka D, Mariotto A (2011) Economic burden of cancer in the United States: estimates, projections, and future research. Cancer Epidemiol Prev Biomarkers 20:2006-2014. https://doi.org/10.1158/1055-9965.EPI-11-0650

Figures

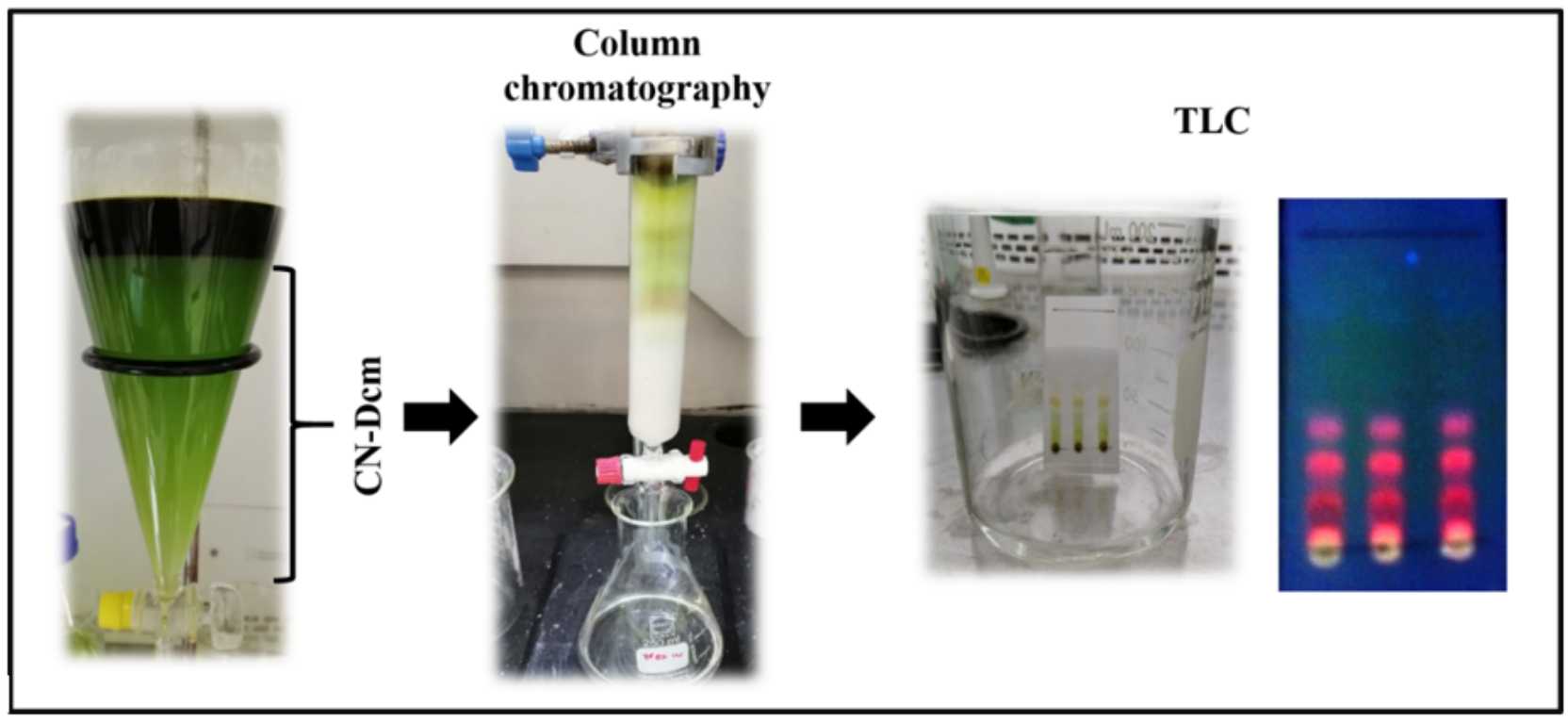

Figure 1

The sub fractionation process of CN-Dcm extract using glass column chromatography. The similarity of $R_{f}$ values from TLC analysis were pooled together and lyophilised. 
$\mathbf{A}$

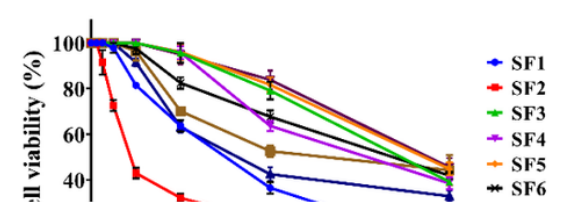

B

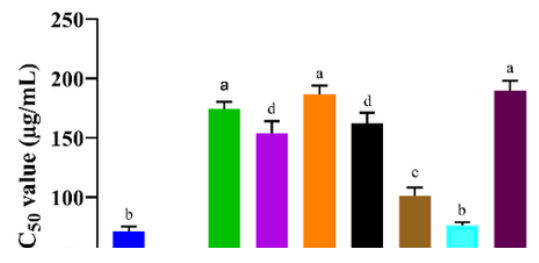

\section{Figure 2}

The cell viability of MCF7 and MCF 10A cells treated with sub fraction extracts using MTS assay at $72 \mathrm{~h}$. (a) MCF7 cells treated with sub fraction extracts, (b) IC 50 values of treated MCF7 cells, (c) MCF 10A cells treated with sub fraction extracts, (d) IC ${ }_{50}$ values of treated MCF 10A cells and (D) SI value of sub fraction extracts. The data represent mean $\pm S D, n=3$. The level of significance: $p<0.05$ using one-way Anova test. Different lowercase characters represent significance differences. 

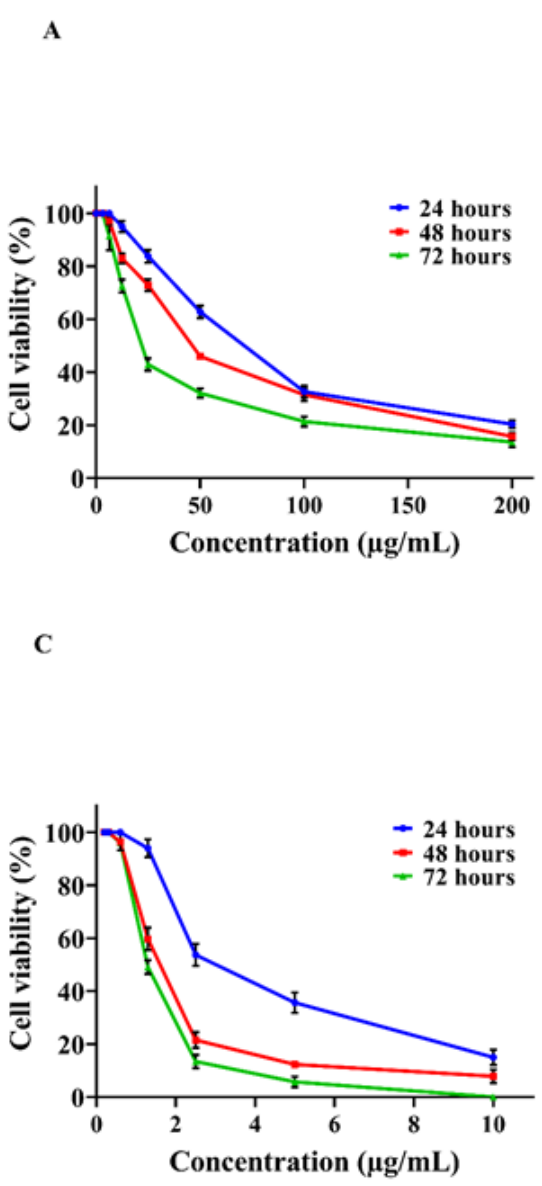
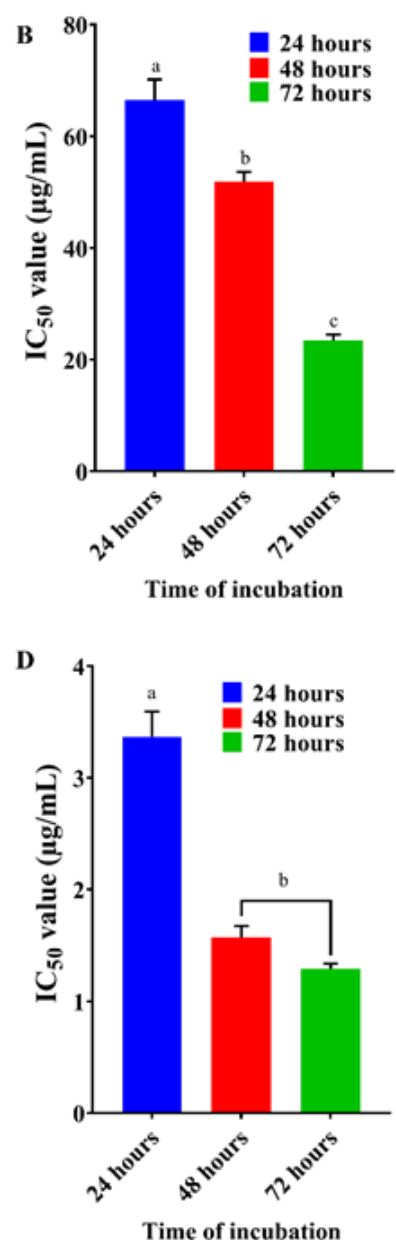

\section{Figure 3}

Cell viability of MCF7 cancer cells treated with SF2 extract and tamoxifen at 24, 48 and $72 \mathrm{~h}$. (A) Antiproliferative effect of MCF7 cells treated with SF2 extract, (B) The IC ${ }_{50}$ value of the SF2 extract against MCF7 cells, (C) Antiproliferative effect of MCF7 cells treated with tamoxifen and (D) The IC ${ }_{50}$ value of the tamoxifen against MCF7 cells. The data represent mean \pm SD, $n=3$. The level of significance: $p<0.05$ using one-way Anova test. Different lowercase characters represent significance differences. 
$\mathbf{A}$

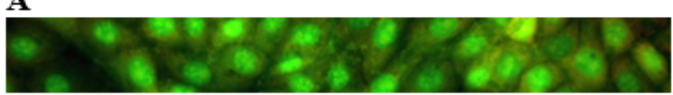

B

ga.

\section{Figure 4}

The morphological changes of untreated and treated MCF7 cells stained with AO/PI dye at 40x magnification (20 $\mu \mathrm{m})$ using inverted fluorescence microscope. (A) Untreated MCF7 cells (B) SF2-treated MCF7 cells (C) Tamoxifen-treated MCF7 cells.

$\mathbf{A}$

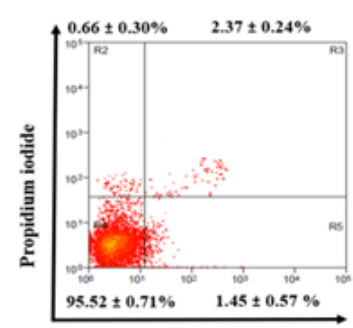

Annexin V-FITC

\section{B}

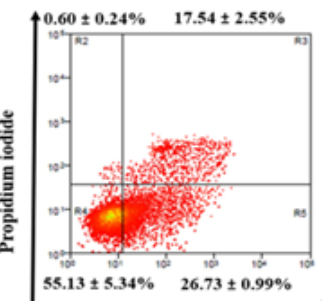

Annexin V-FITC

D
C

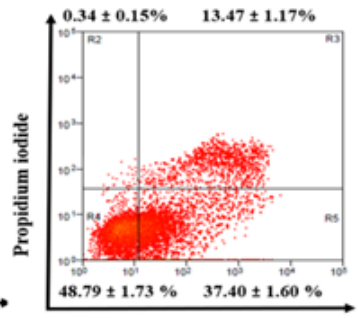

Annexin V-FITC

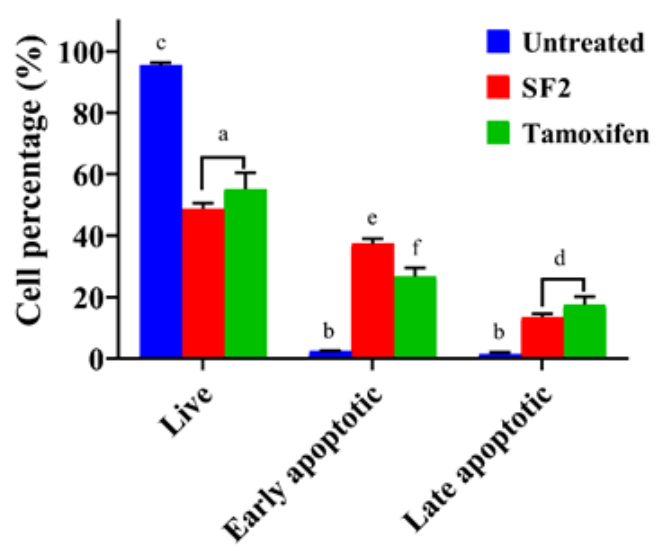




\section{Figure 5}

Flow cytometry analysis of MCF7 cells stained with Annexin V-FITC and PI dye. (a) Untreated MCF7 cells, (b) SF2-treated MCF7 cells and (c) Tamoxifentreated MCF7 cells (d) Percentage of cells stage (live, early apoptosis and late apoptosis) in MCF7 cells. The data represent mean \pm SD, $n=3$. The level of significance: $p<0.05$ using two-way Anova test. Different lowercase characters represent significance differences.

A

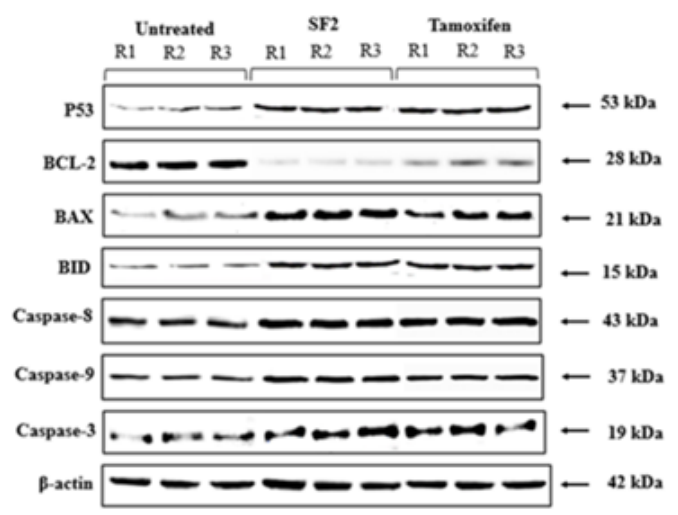

B

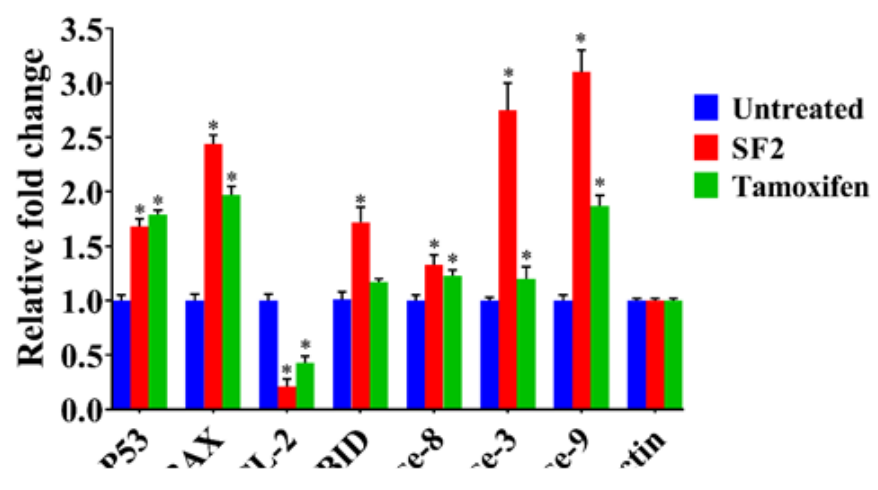

Figure 6

Protein expressions of MCF7 cells. (A) Representative image of proteins expression and $\beta$-actin was used as a loading control. (B) Relative fold change of protein expressions expressed as mean \pm SD. The level of significance: $p<0.05$ using two-way Anova test. Asterisk symbol represent significance differences compared to untreated MCF7 cells.

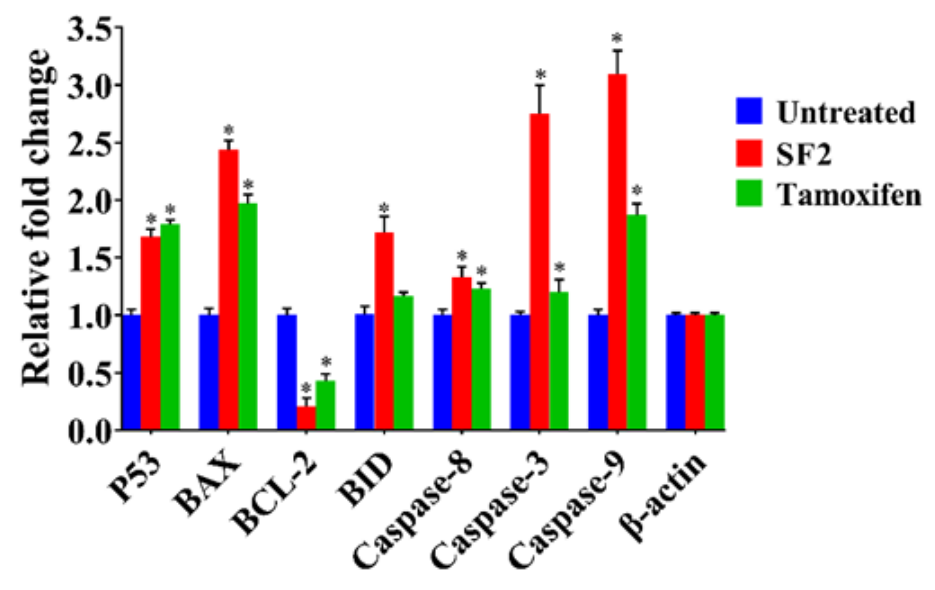


Figure 7

The genes expression of untreated control and treated MCF7 cells at $72 \mathrm{~h}$. Relative fold change of genes expression were expressed as mean \pm SD for triplicate. The level of significance: $p<0.05$ using two-way Anova test. Asterisk symbol represent significance differences compared to untreated MCF7 cells.

\section{Supplementary Files}

This is a list of supplementary files associated with this preprint. Click to download.

- Supplementaryfiles.doc 